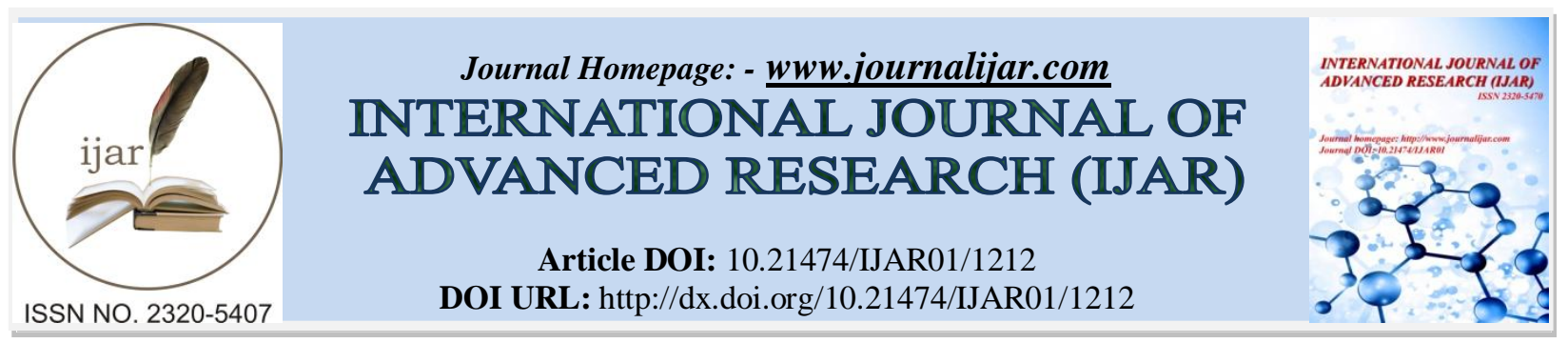

\title{
RESEARCH ARTICLE \\ DETERMINATION OF POLYCYCLIC AROMATIC HYDROCARBONS IN FOUR FISH PELAGIC SPECIES ALONG THE MOROCCAN COASTS.
}

\section{*NDADANI Fatima Zahra ${ }^{1,2}$, ZKHIRI Fouzia ${ }^{1}$, RACHIDI Abderrazzak ${ }^{2}$}

1. Laboratory of Virology, Microbiology \& Quality/Eco-toxicology and Biodiversity, Department of Biology Faculty of Science and Techniques Mohammedia, Hassan II University Casablanca, Morocco.

2. National Office for Health Security of Food Products, Regional Laboratory of Analysis and Research Casablanca, Morocco.

\section{Manuscript Info}

\section{Manuscript History}

Received: 13 June 2016

Final Accepted: 11 July 2016

Published: August 2016

Key words:

Benzo(a)pyrene

Spatial analysis

Toxicity

Fish

\section{Abstract}

Benzo (a) pyrene (BaP) is part of a class of chemicals called polycyclic aromatic hydrocarbons (PAH). PAHs are a large group of ubiquitous and toxic environmental contaminants. They are under the control of the European Commission (EC) and the Environmental Protection Agency (EPA). Human can be exposed to PAHs through breathing, skin contact and ingestion. The aim of this paper is to evaluate the (BaP) contamination of sardine, mackerel, anchovy and horse mackerel species that originate from the Atlantic and Mediterranean Oceans. The analysis has been performed by gas chromatography coupled with mass spectrometry (GC-MS) in selected ion monitoring (SIM) mode. The results revealed a measurable presence of $(\mathrm{BaP})$ in foodstuffs, yet also exhibited the minimal existence of $(\mathrm{BaP})$ values with fluctuations also variants. The levels detected in these products showed a compliance of the fish with the global essential safety requirements of the European commission.

Copy Right, IJAR, 2016,. All rights reserved.

\section{Introduction:}

Polycyclic aromatic hydrocarbons (PAHs) are one of the several classes of organic pollutants found in the marine ecosystem. Sources of PAHs in aquatic ecosystem include atmospheric fallouts, spills of crude oils or its products and combustion processes (Storelli et al, 2013). These compounds are generated naturally in volcanic eruptions, plant emissions, geochemical formation of fossil fuels and forest fires (Nguyen et al, 2014). The main anthropogenic sources of PAHs are the partial combustion of organic substances, waste incineration, industrial activity and domestic heating (Clemente et al, 2014; Zhao et al, 2014). PAHs are removed from the atmosphere during the vapor-phase adsorbed to aerosol particles, which are then deposited on water and soil (Orecchio, 2007). These organic compounds are hydrophobic and highly lipophilic as they have complex molecular structure and low solubility in water (Perrichon et al, 2015; Singh et al, 2016). PAHs, as persistent organic pollutants (POPs) create a significant environmental hazard and potential danger to human health due to their carcinogenicity and genotoxicity (Liu et al, 2013). The International Agency for Research on Cancer (IARC), the Agency of Toxic Substances and Disease Register (ATS-DR), the European Union and the Environmental Protection Agency have all mentioned PAHs as priority pollutants (Singh et al, 2016). Four-to-six-ring PAHs are highly mutagenic and carcinogenic, while two-to-three-ring PAHs are less mutagenic but still remain highly toxic (Xiao et al, 2014). These compounds are classified as carcinogenic as they are metabolized to dihydrodiols by hydrocarbons hydroxylases present in the liver.

Corresponding Author: NDADANI Fatima Zahra.

Address: Laboratory of Virology, Microbiology \& Quality/Eco-toxicology and Biodiversity, Department 
Dihydrodiols and their epoxide derivatives bind to DNA and proteins, starting mutagenic processes in the cells (Liguori et al, 2006). It has been well demonstrated that (BaP) exhibited toxic effects on cells and tissues, can cause cancer in whole-animal assay, and also affects reproduction (Gregory et al, 2016; Li et al, 2016). The EFSA panel on contaminants in the food chain recommended four substances (Benzo (a) pyrene, benzo(a)anthracene, benzo (b) fluoranthene and chrysene) as the only possible indicators of PAHs in food, however its quoted separately a maximum level for benzo (a) pyrene in order to ensure comparability between the earlier and later data. For that, the EC Regulation introduced new Regulation No 835/2011 amending Regulation No 1881 / 2006 (European commission, 2011). Our study is involved in a program regarding seafood safety. The primary aim of the present study was to analyze the levels of $(\mathrm{BaP})$ in four pelagic fish species Sardina pilchardus, Scomber japonicus, Engraulis encrasicolus, Trachurus trachurus. The second purpose was to assess the spread of contamination and to evaluate the intra and inter-specific variability.

\section{Experimental:}

\section{Chemicals and Materials:}

All solvents (N.Hexane, dichloromethane, isooctane) were of GC grade (Scharlau, Spain), where water was purified by a Milli-Q system. The standard solution of benzo(a) pyrene was supplied by Isotec chemicals.

\section{Sample collection and chemical analysis:}

The samples were collected from Moroccan coast cities that face the Atlantic and Mediterranean Oceans and are the main ports of the Moroccan kingdom, they include: Dakhla, Laayoun, Tantan, Agadir, Safi, Essaouira, Casablanca, Kenitra, Tangier and Tetouan (Fig.1). The fish were collected over a period extending from September 2014 to December 2015 and cover a variety of marine species (sardine, mackerel, anchovy and horse mackerel). The samples collected were transported to the laboratory in polyethylene bags, stored in ice and processed immediately upon arrival. The samples were extracted using a method known as sonication (Branson 3200), we then used chromatographic purification with florisil and $\mathrm{MgSO} 4$ in a glass column. Ultrasonic extraction was selected as it reduces both the volume of organic solvents and the extraction time required. The gas chromatograph-mass spectrometer (QP2010plus, Shimadzu, Japan) was used for analytical determination. Separation of compounds was performed on Column: sol-gel column with a length of $(30 \mathrm{~m} \mathrm{x} 0.25 \mathrm{~mm}$ ID x $0.25 \mu \mathrm{m}$ film thickness). Electron impact associated to single-ion monitoring (SIM) was used as the operating system (Song, 2012; Purcaro, 2013; Mohammadi, 2013). The optimized gas chromatography-mass spectrometry (GC-MS) method allows a wide range of concentrations to be analyzed without the influence of interferences (Orecchio, 2007; Szulejko, 2014).

\section{Statistical analysis:}

Data was expressed as mean \pm standard deviation and the statistical calculation was accessed using the (SPSS v21). All the tests were performed using the three-way analysis of variance (ANOVA) and the significance of the results was ascertained at $\alpha=0.05$.

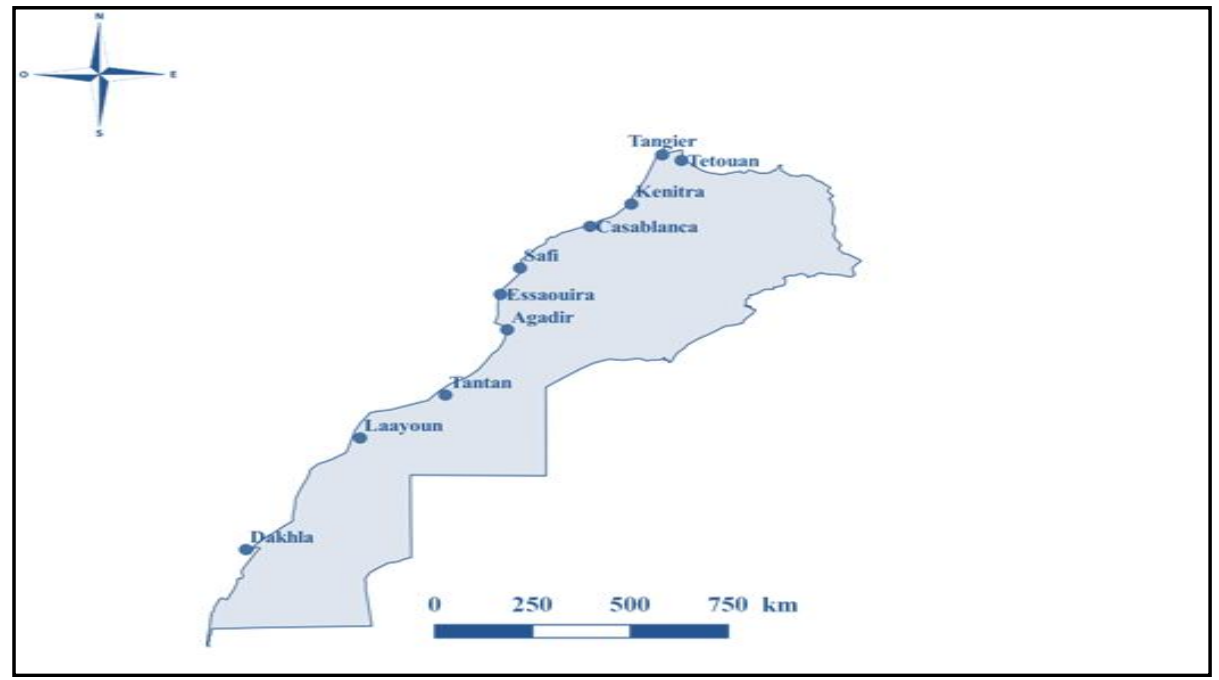

Fig.1: Geographical location of sampling stations along the Moroccan coasts. 


\section{Results:}

The regrouped data of species are statistically analyzed and presented in Table 1. Upon examination of tabulated values, it is seen that the total average concentration of (BaP) was $1,26 \pm 0,27 \mu \mathrm{g} / \mathrm{kg}$. The concentrations of $\mathrm{B}(\mathrm{a}) \mathrm{P}$ ranged from 0,06 to 1,15 for mackerel, 0,06 to 1,96 for sardine, 0,14 to 1,20 for Anchovy, and horse mackerel 0,05 to 0,61 . Chemical structure of $(\mathrm{BaP})$ is shown in Fig.2. Fig.3 displays the chromatogram obtained for $(\mathrm{BaP})$ using the mass spectrometer in SIM mode. The MS spectrum for $(\mathrm{BaP})$ could thus be analyzed and then assigned GC-peak with its retention time. The MS was operated in Selective Ion Monitoring (SIM) mode to maximize the detection of several target constituents using the retention times, target response factors, and integrations. The (BaP) concentration in $\mu \mathrm{g} / \mathrm{kg}$ of wet weight tissue was quantified. The spatial variation of $(\mathrm{BaP})$ was presented in Fig.4, the results obtained show that there were a significant differences between sites. The temporal variations and the levels of the detected (BaP) in the several fish species are presented in Fig. 5 and Fig.6, the bars and the whiskers represent the median and the inter quartile range. Box and whisker plots seek to explain data by summarizing a set of data measured on an interval scale. We can get an idea of the central disposition of each box values by observing the median position between different species and also among seasons. Furthermore the length of the box, it is possible to estimate the variability of values for each group. The median seems generally lower for the species and for seasons. The ANOVA test indicated that there is a significant variation among sampling areas $(\mathrm{p}<0.05)$. No significant differences in the (BaP) were observed for seasons and species ( $>0.05)$ (Table 2). Fig. 7 and fig. 8 show the spatial distribution of $(\mathrm{BaP})$ along the Moroccan coastal. These two figures represent the projection of the average concentrations present at each site selected for this monitoring campaign. The concentration of $(\mathrm{BaP})$ in fish products show that the obtained levels are below the limit values laid down in Regulation N ${ }^{\circ} 835 / 2011$ (oils and fats complied with the maximum levels of $2 \mu \mathrm{g} / \mathrm{kg}$ for $\mathrm{BaP}$ ).

Table 1: Concentration levels $(\mu \mathrm{g} / \mathrm{Kg})$ of benzo(a)pyrene in fish species.

\begin{tabular}{|c|l|c|c|c|}
\hline \multicolumn{5}{|c|}{ Benzo (a) pyrene } \\
\hline Species & Average & Standard deviation & Minimum value & Maximum value \\
\hline Mackerel & $\mathbf{0 , 3 0}$ & $\mathbf{0 , 2 2}$ & $\mathbf{0 , 0 6}$ & $\mathbf{1 , 1 5}$ \\
\hline Sardine & $\mathbf{0 , 2 8}$ & $\mathbf{0 , 4 1}$ & $\mathbf{0 , 0 6}$ & $\mathbf{1 , 9 6}$ \\
\hline Anchovy & $\mathbf{0 , 2 9}$ & $\mathbf{0 , 3 0}$ & $\mathbf{0 , 1 4}$ & $\mathbf{1 , 2 0}$ \\
\hline Horse mackerel & $\mathbf{0 , 3 9}$ & $\mathbf{0 , 1 7}$ & $\mathbf{0 , 0 5}$ & $\mathbf{0 , 6 1}$ \\
\hline
\end{tabular}

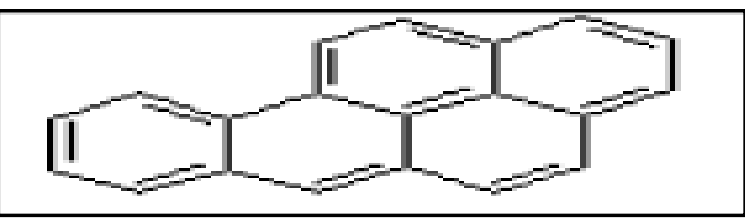

Fig.2: Chemical structure of benzo (a) pyrene.

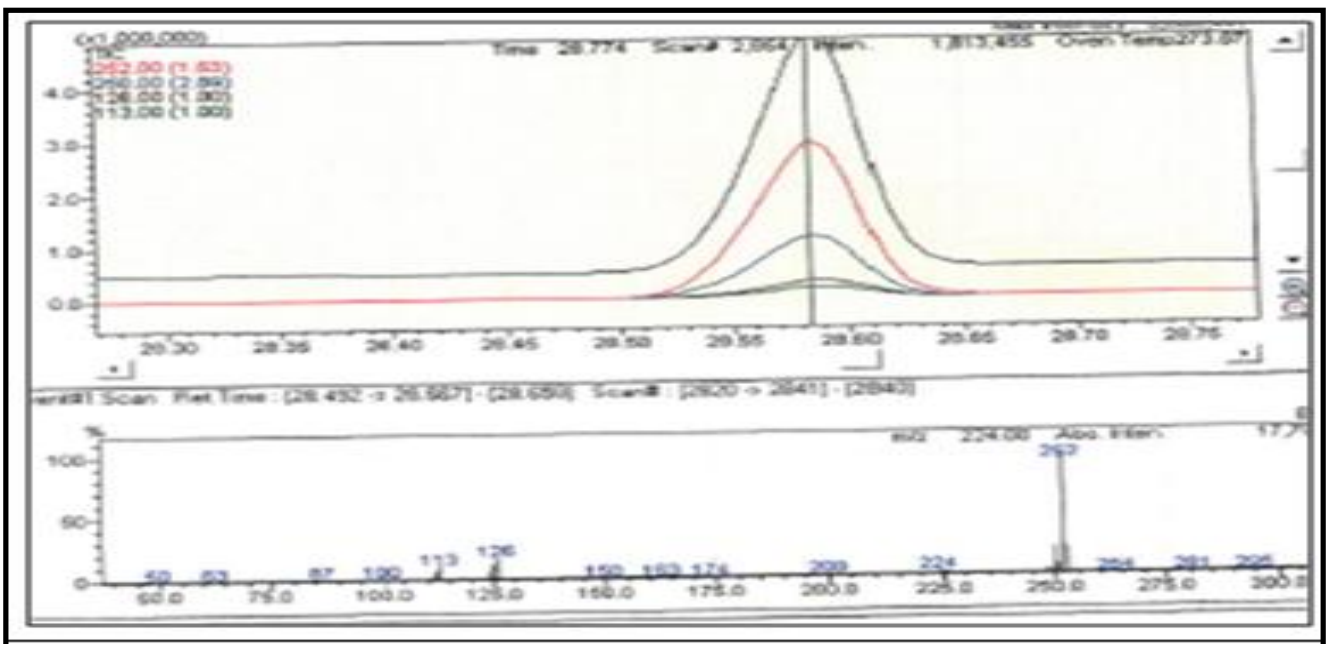

Fig.3: Selected Ion Monitoring Scan of the Benzo (a) pyrene in the fish extract. 


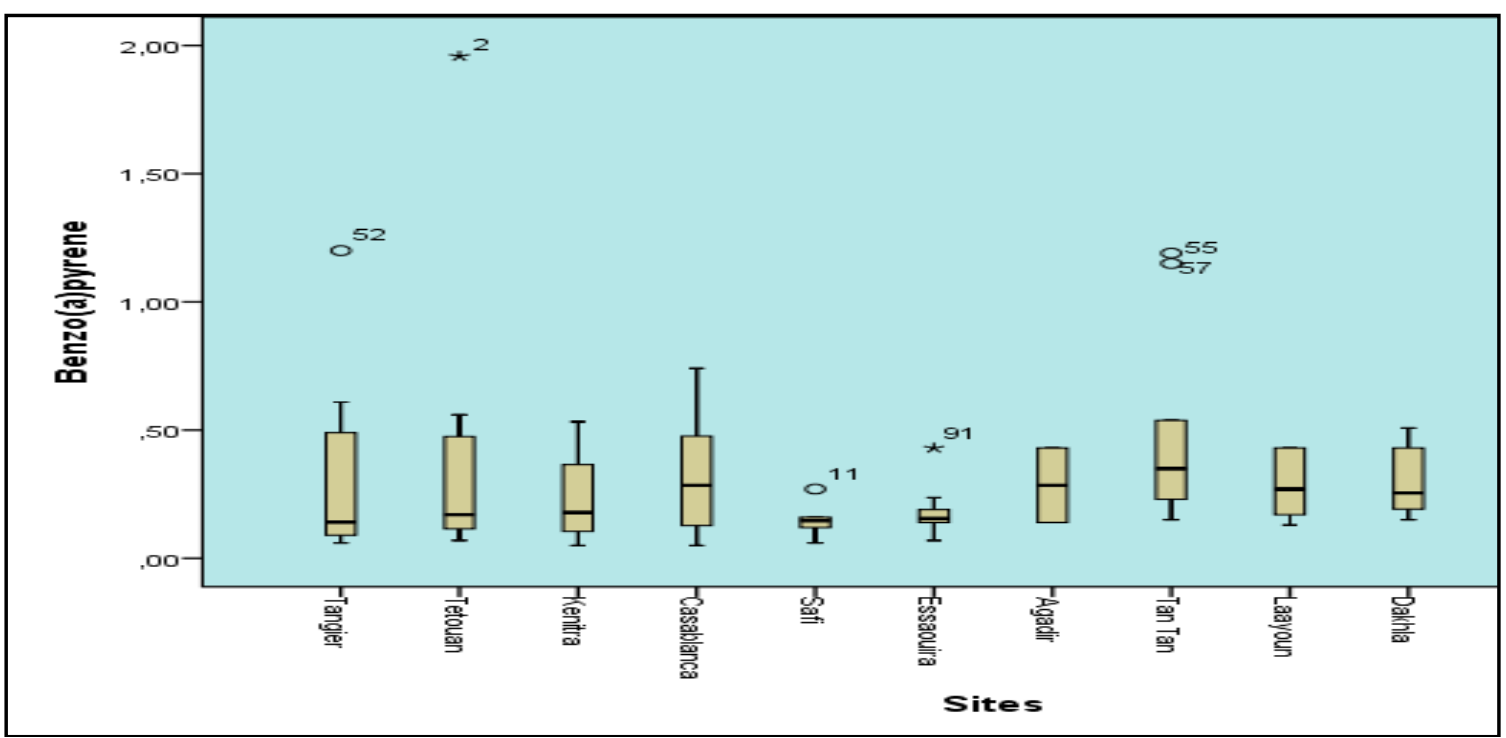

Fig.4: Spatial variation of benzo(a) pyrene in fish.

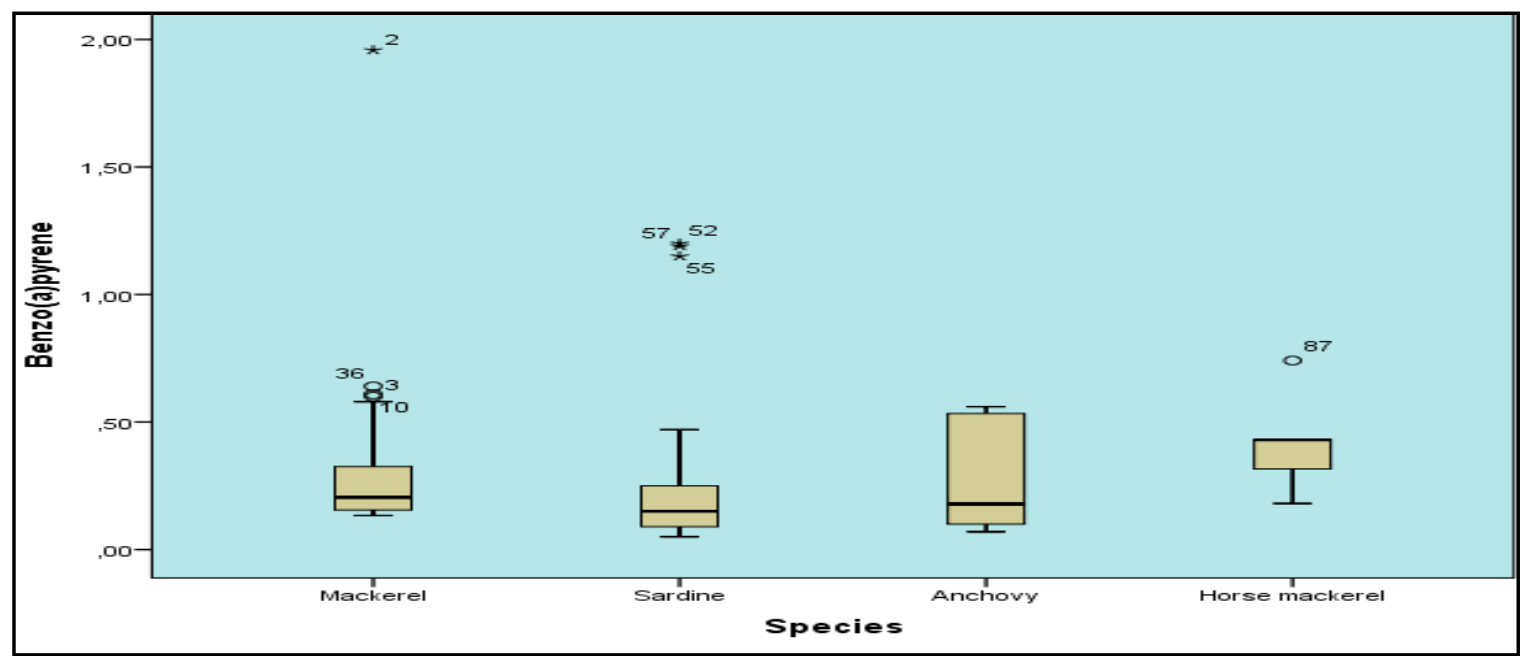

Fig.5: Concentrations of benzo (a) pyrene in four pelagic fish species.

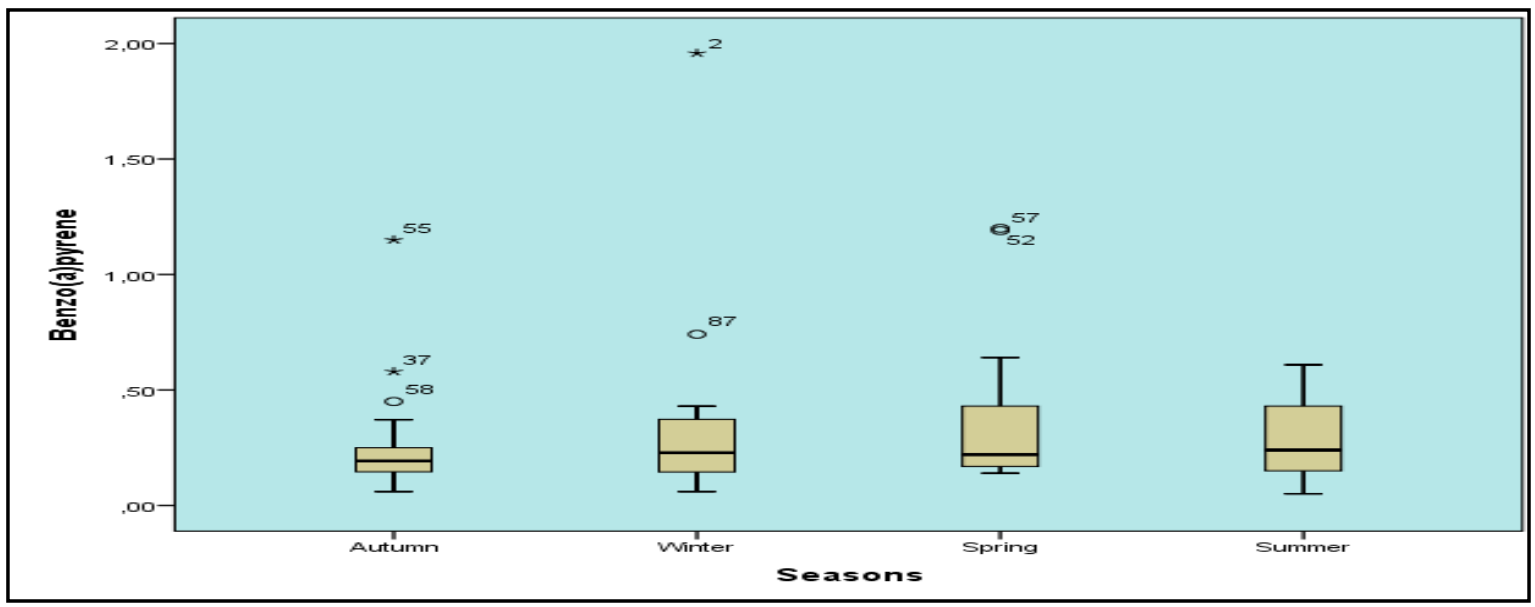

Fig.6: Seasonal variation of benzo(a) pyrene in fish . 
Table 2: Analysis of variance of benzo (a) pyrene by Sampling stations, Seasons and Species.

\begin{tabular}{|c|c|c|c|}
\hline \multicolumn{4}{|c|}{ Benzo (a) pyrene } \\
\hline & F & Sig & State \\
\hline Sites & $\mathbf{2 , 0 3 3}$ & $\mathbf{0 , 0 3 1}$ & Significant \\
\hline Seasons & $\mathbf{0 , 6 6}$ & $\mathbf{0 , 5 7}$ & No Significant \\
\hline Species & $\mathbf{0 , 9 2}$ & $\mathbf{0 , 5 2}$ & No Significant \\
\hline
\end{tabular}

$*[F=$ F-statistic; Sig: Significance means $p$ value; $p$ value $<0.05$ : Significance difference; $p$ value $>0.05$ : No Significance difference]

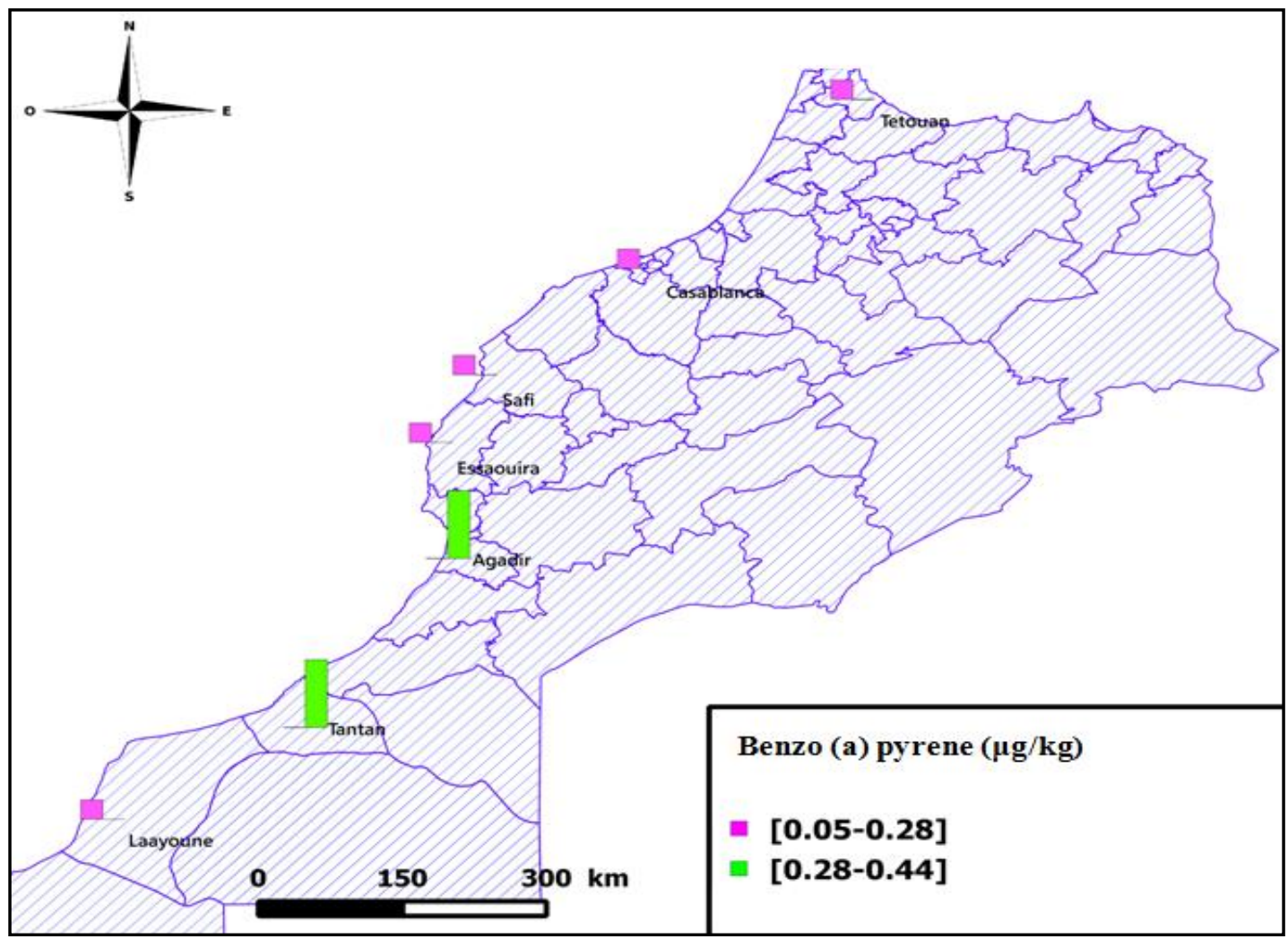

Fig.7: Spatial variation of benzo (a) pyrene in various sites along the Moroccan coasts. 


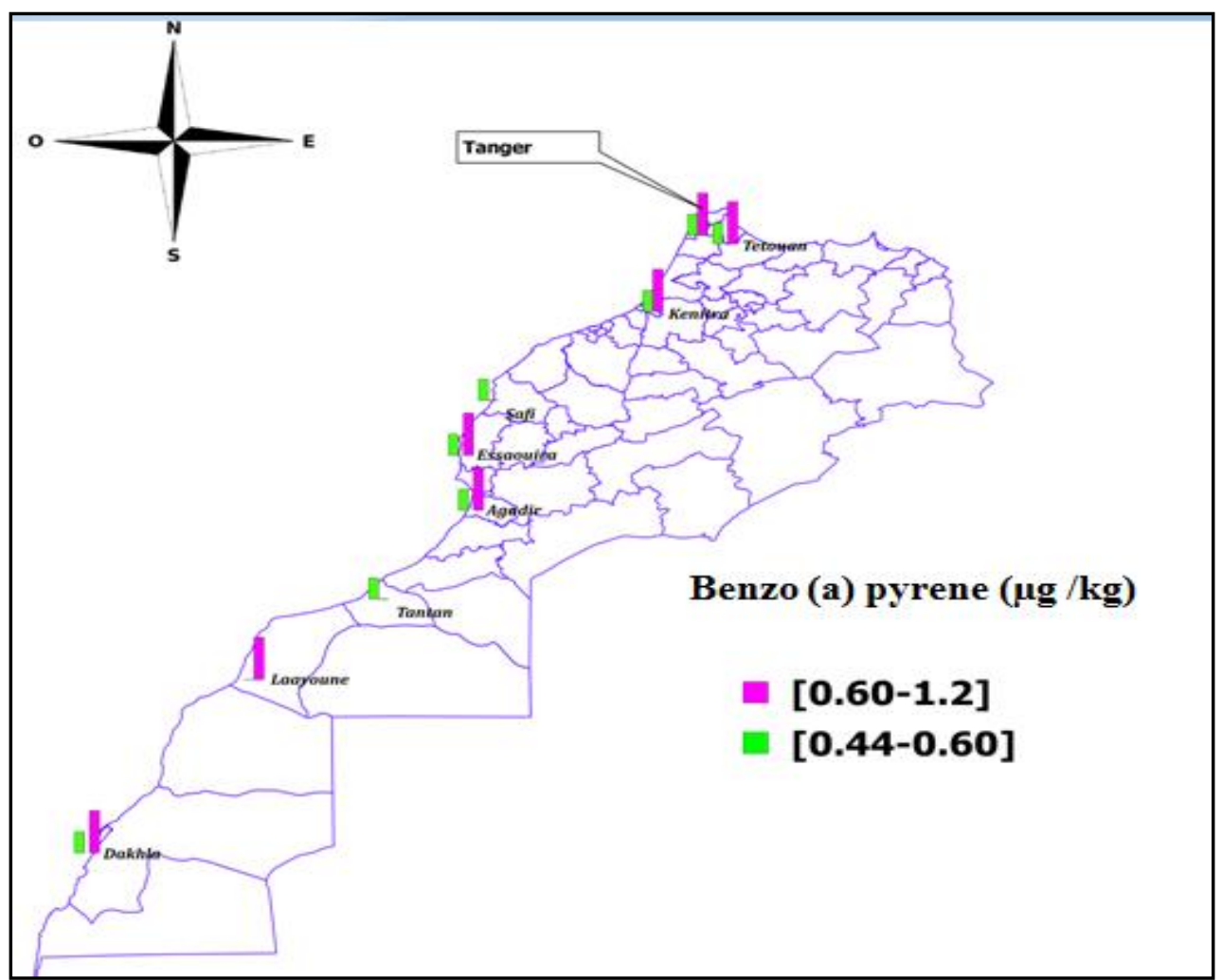

Fig.8: Spatial variation of benzo (a) pyrene in several sites along the Moroccan coasts.

\section{Discussion:}

The maritime fishing sector in our country plays an important role in the economy. However, information about the concentrations of PAH in foodstuffs, as well as on the dietary intake of the contaminants by the populations is limited (Baghdadi et al, 2012). A much more intensive search provided in the scientific literature review notes that Italy, Spain, the United Kingdom, and the Netherlands are the countries with the most reported information on the dietary intake of PAHs (Domingo et al, 2015).

The present study emphasizes on the dietary exposure of humans to (BaP), its occurrence in the different fish species and the proposed interventions for controlling its levels in foodstuffs. In addition, the study looks at the spatial and seasonal variations of $(\mathrm{BaP})$ in fish, to discuss the factors leading to the accumulation of $(\mathrm{BaP})$ in fish products.

Benzo [a] pyrene, which is highly considered because of its carcinogenicity, it induces DNA breaks in oysters (Wessel et al, 2007), development of DNA adducts in zebrafish and human liver cells (Miranda et al, 2006). It may cause also a decrease in weight and growth (Van Brummelen et al, 1996; Chikae et al, 2004), furthermore, it has teratogenic effects in particular on the heart of the sardine and zebrafish (Incardona et al, 2008; Hicken et al, 2011). Identification and quantification of PAHs is often complicated by another compounds present in the sample. To avoid this issue, the GC-MS method was applied to identify the different compounds with the aid of spectra libraries (Purcaro et al, 2013). GC-MS provides conclusive analytical information and it is mainly used for the analysis of environmental samples containing organic compounds. This method has been tested on different biological marine matrixes, namely mackerel, sardine, anchovy and horse mackerel.

The impact of sampling areas on $(\mathrm{BaP})$ values, which proves that spatial variation influence on the concentrations of these molecules, data obtained for sites are consistent with those observed by Baghdadi (2012) .The statistical analysis obtained for species and seasons were comparable. These results are not consistent with the results of Ramalhosa (2012) and Gomes (2013) whom demonstrate that the nature and characteristics of species are influenced on the (BaP) levels. Other studies executed in Europe show an annual cyclic variation which seems chronologically related to the seasonal variations of biotic and a biotic factor regulating metabolic mechanisms and PAHs bioaccumulation (Zhao et al, 2014). 
The system of geographic information performs spatial analysis and topological connection (Dauner et al, 2016). The sites covered by this study used for the exposure estimation to $(\mathrm{BaP})$ are broadly consistent, thereby proved the impact of spatial variations. In view maps, it was found that the highest concentration occurred in Tangier, Tetouan, Kenitra, Laayoun and Dakhla. These areas are known for a strong urban and industrial contamination. Figure 7 and figure 8 reveal the spatial variation approved by the majority of studies on chemical contamination that were also approved by ANOVA variations. The spatial distributions of pollution sources were related to geographic location and condition, fish collected from polluted locations generally contain detectable amounts of (BaP). The presence of $(\mathrm{BaP})$ in fish depends on the physiological and ecological characteristics of the fish (Domingo et al, 2015). Also due to toxic character and low aqueous solubility of this substance. The lipid content of tissues can be a primary factor in the bioaccumulation of $(\mathrm{BaP})$ in fish. Consequently previous study revealed that $(\mathrm{BaP})$ is photo degraded more easily than its isomer CHR during transportation, the ratio of BaP/CHR can be used as an indicator for the degree of photo degradation (Liu et al, 2012). The concentrations of (BaP) in our study were below those observed in highly urbanized and industrialized regions of Italy and china (Dauner et al, 2016). Furthermore, no species exceed the maximum levels set by the Commission Regulation (EC) $\mathrm{N}^{\circ} 835 / 2011$.

\section{Conclusion:}

Marine species consumption differs between countries, even within countries it differs among segments of society. Mackerel, sardine, anchovy, horse mackerel are the important commercial species of the Moroccan coastal. A great effort has been devoted to determine $(\mathrm{BaP})$ in complex samples, such as fish products to evaluate whether such contamination levels may pose risks to human health. In this context the aim of the present study was to analyze the presence of $(\mathrm{BaP})$ in pelagic fish. The results of this survey of $(\mathrm{BaP})$ in various pelagic species revealed that measurable levels of $(\mathrm{BaP})$ were very low. Spatial variation revealed such samples had the lowest concentration. The seasonal variation was obvious. No significant differences in the concentration of the (BaP) were observed. In this study no species exceed the maximum levels enacted by (EC) legislation $\mathrm{N}^{\circ} 835 / 2011$. The levels of (BaP) detected in fish products does not seem to pose a risk to the health status.

\section{References:}

1. Baghdadi Mazini, D., Rachidi, A., Maatouk, M ., Noël, L., Barrijal, S.2012: Dosage des HAP dans les produits de pêche par GC-MS au niveau des côtes marocaines. Les technologies de laboratoire., 7: 90-98.

2. Chikae, M., Hatano, Y., Ikeda, R., Morita, Y., Hasan, Q., Tamiya, E. 2004: Effects of bis(2-ethylhexyl) phthalate and benzo[a]pyrene on the embryos of Japanese medaka (Oryzias latipes). Environmental Toxicology and Pharmacology., 16: 141-145.

3. Clemente, A., Torres-Palma, R., Peñuela, G., 2014 : Removal of polycyclic aromatic hydrocarbons in aqueous environment by chemical treatments: A review. Science of the Total Environment., 478: 201-225.

4. Commission Européenne. 2011 : Règlement (UE) n 835/2011 de la commission du 19 Août 2011. Journal officiel de l'Union Européenne. Bruxelles.

5. Dauner, A., Lourenço, R., Martins, C. 2016 : Effect of seasonal population fluctuation in the temporal and spatial distribution of polycyclic aromatic hydrocarbons in a subtropical estuary. Environmental Technology \& Innovation., 5: 41-51 .

6. Domingo, J., Nadal, M .2015: Human dietary exposure to polycyclic aromatic hydrocarbons: A review of the scientific literature. Food and Chemical Toxicology., 86: 144-153.

7. Gomes, F., Oliveira, M., Ramalhosa, M., Delerue-Matos, C., Morais, S. 2013: Polycyclic aromatic hydrocarbons in commercial squids from different geographical origins: Levels and risks for human consumption. Food and Chemical Toxicology., 59: 46-54.

8. Gregory, M., Meyer, B., Portier, R .2016: Assessment of the toxic potential of polycyclic aromatic hydrocarbons(PAHs) affecting Gulf menhaden (Brevoortia patronus) harvested from waters impacted by the BP Deepwater Horizon Spill. Chemosphere., 145: 322-328.

9. Hicken, C.E., Linbo, T.L., Baldwin, D.H., Willis, M.L., Myers, M.S., Holland, L., Larsen, M.,Stekoll, M.S., Rice, S.D., Collier, T.K., Scholz, N.L., Incardona, J.P. 2011: Sublethal exposure to crude oil during embryonic development alters cardiac morphology and reduces aerobic capacity in adult fish. Proceedings of the National Academy of Sciences of the United States of America., 108: 7086-7090.

10. Incardona, J.P., Carls, M.G., Day, H.L., Sloan, C.A., Bolton, J.L., Collier, T.K., Scholz, N.L. 2008: Cardiac Arrhythmia Is the Primary Response of Embryonic Pacific Herring (Clupea pallasi) Exposed to Crude Oil during Weathering. Environmental Science \& Technology., 43: 201-207. 
11. Li, G., Wu, S., Wang, L., Akoh, C.2016: Concentration, dietary exposure and health risk estimation of polycyclic aromatic hydrocarbons (PAHs) in youtiao, a Chinese traditional fried food. Food Control., 59:328336.

12. Liguori, L., Heggstad, K., T-Hove, H., Julshamn, K. 2006: An automated extraction approach for isolation of 24 polyaromatic hydrocarbons (PAHs) from various marine matrixes. Analytica Chimica Acta .,573-574:181188.

13. Liu, L., Wang, J., Wei, G., Guan, Y., Zeng, E. 2012: Polycyclic aromatic hydrocarbons (PAHs) in continental shelf sediment of China: Implications for anthropogenic influences on coastal marine environment . Environmental Pollution., 167: 155-162.

14. Liu, F., Liu, J., Chen, Q., Wang, B \& Cao, Z. 2013: Pollution characteristics and ecological risk of polycyclic aromatic hydrocarbons (PAHs) in surface sediments of the southern part of the Haihe River system in China.Chinese Science Bulltin., 58: 3348-3356.

15. Miranda, C.L., Chung, W.G., Wang-Buhler, J.L., Musafia-Jeknic, T., Baird, W.M., Buhler,D.R. 2006: Comparative in vitro metabolism of benzo[a]pyrene by recombinant zebrafish CYP1A and liver microsomes from [beta]-naphthoflavone-treated rainbow trout. Aquatic Toxicology ., 80: 101-108.

16. Mohammadi, A., Mohammadi, V., Haratian, P., Khaksar, R., Chaich, M. 2013: Determination of polycyclic aromatic hydrocarbons in smoked fish samples by a new microextraction technique and method optimization using response surface methodology. Food Chemistry., 141:2459-2465.

17. Nguyen, T., Loganathan, P., Nguyen, T., Vigneswaran, S ., Kandasamy, J., Slee, D., Stevenson, G., Naidu, R. 2014: Polycyclic aromatic hydrocarbons in road-deposited sediments, water sediments, and soils in Sydney, Australia: Comparisons of concentration distribution, sources and potential toxicity. Ecotoxicology and Environmental Safety., 104:339-348.

18. Orecchio, S. 2007: PAHs associated with the leaves of Quercus ilex L: Extraction, GC-MS analysis, distribution and sources Assessment of air quality in the Palermo (Italy) area. Atmospheric Environment., 41: 8669-8680.

19. Perrichon, P., Akcha, F., Menach, K., Goubeau, M., Budzinski, H., Cousin, X., Bustamante, P. 2015: Parental trophic exposure to three aromatic fractions of polycyclic aromatic hydrocarbons in the zebrafish: Consequences for the offspring. Science of the Total Environment ., 524-525 : 52-62.

20. Purcaro, G., Moret, S ., Conte, L. 2013: Overview on polycyclic aromatic hydrocarbons: Occurrence, legislation and innovative determination in foods. Talanta ., 105: 292-305.

21. Ramalhosa, M., Paíga, P., Morais, S., Sousa, A., Gonçalves, M., Delerue-Matos, C., Oliveira, M. 2012 : Analysis of polycyclic aromatic hydrocarbons in fish: Optimisation and validation of microwave-assisted extraction. Food Chemistry., 135: 234-242.

22. Singh, L., Varshney, J., Agarwal, T.2016: 'Polycyclic aromatic hydrocarbons' formation and occurrence in processed food. Food Chemistry., 199: 768-781.

23. Song, X., Li J; Xu S., Ying, R., Mac, J., Liao, C., Liu, D., Yu, J. Chen, L.2012: Determination of 16 polycyclic aromatic hydrocarbons in seawater using molecularly imprinted solid-phase extraction coupled with gas chromatography-mass spectrometry. Talanta., 99:75-82.

24. Storelli, M., Barone, G., Perrone, P., Storelli, A.2013: Risk characterization for polycyclic aromatic hydrocarbons and toxic metals associated with fish consumption. Journal of Food Composition and Analysis., 31:115-119.

25. Szulejko, JE., Kim, K., Brown, R., Bae, M. 2014: Review of progress in solvent-extraction techniques for the determination of polyaromatic hydrocarbons as airborne pollutants. Trends in Analytical Chemistry.,61:40-48.

26. Van Brummelen, T.C., Van Gestel, C.A.M., Verweij, R.A. 1996: Long-term toxicity of five polycyclic aromatic hydrocarbons for the terrestrial isopods Oniscus Asellus and Porcellio Scaber. Environmental Toxicology and Chemistry., 15: 1199-1210.

27. Wessel, N., Rousseau, S., Caisey, X., Quiniou, F., Akcha, F. 2007: Investigating the relationship between embryotoxic and genotoxic effects of benzo[a]pyrene, 17[alpha]-ethinylestradiol and endosulfan on Crassostrea gigas embryos. Aquatic Toxicology., 85: 133-142.

28. Xiao, R., Bai, J., Wang, J., Lu, Q., Zhao, Q., Cui, B., Liu, X. 2014 : Polycyclic aromatic hydrocarbons (PAHs) in wetland soils under different land uses in a coastal estuary: Toxic levels, sources and relationships with soil organic matter and water-stable aggregates.Chemosphere., 110: 8-16.

29. Zhao, Z ., Zhang, L., Cai, Y., Chen, Y. 2014 : Distribution of polycyclic aromatic hydrocarbon(PAH) residues in several tissues of edible fishes from the largest fresh water lake in China, Poyang Lake, and associated human health risk assessment. Ecotoxicology and Environmental Safety., 104: 323-331. 